\title{
Turkish version of the Tilburg Frailty Indicator
}

This article was published in the following Dove Medical Press journal:

Clinical Interventions in Aging

\section{Yildiray Topcu \\ Fatih Tufan \\ Cihan Kilic}

Department of Geriatrics, Istanbul School of Medicine, Istanbul

University, Istanbul, Turkey
Correspondence: Fatih Tufan Silivrikapi mh. Hisaralti cd. Fatih sitesi AI blok D9 Fatih, Istanbul, Turkey

Tel +90 $533 \quad 1683458$

Email fatihtufan@gmail.com
Background: Recently frailty has drawn significant interest as an important predictor of several clinically relevant outcomes. There is no widely accepted instrument for the assessment of frailty and most of the current ones evaluate only physical features. The Tilburg Frailty Indicator (TFI) is a valid and reliable instrument which enables multidimensional assessment of frailty. We aimed to adapt and evaluate the Turkish version of the TFI.

Methods: We translated and culturally adapted the English version of the TFI into Turkish using standard guidelines. We enrolled consecutive patients who were 70 years old or older and were admitted to our outpatient geriatrics clinic. We used Cronbach's alpha values to evaluate the internal consistency and also assessed inter-observer and test-retest variability using intraclass correlation coefficient (ICC).

Results: The Cronbach's alpha reliability coefficients of the instrument ranged from 0.65 to 0.72 and item-total correlation ranged between -0.05 and 0.57 . There was a good agreement between two assessments ( $\mathrm{ICC}=0.99$ ) and between two observers ( $\mathrm{ICC}=0.99$ ).

Conclusion: We have shown the reliability of the Turkish version of the TFI as a tool to evaluate frailty in a multidimensional manner among the Turkish outpatient population.

Keywords: Tilburg Frailty Indicator, Turkish version, internal consistency, validity, older individuals, aging, frailty, multidimensional assessment, psychosocial factors, validation study, cultural adaptation, older adults

\section{Introduction}

Along with the decrease in mortality due to chronic conditions, the rate of frailty associated with disabilities increases. Although frailty commonly occurs concomitantly with comorbidities and disability, it is generally accepted as a distinct syndrome. ${ }^{1}$ Frailty is commonly defined as a combination of unintentional weight loss, weakness, slow walking speed, fatigue, and low activity levels. ${ }^{2}$ Frailty is closely associated with adverse health outcomes such as loss in functional capacity, falls, hospitalization, and death. ${ }^{3,4}$ Various instruments which aimed to detect frailty such as the Cardiovascular Health Study Phenotype Model and Study of Osteoporotic Fracture Criteria for Frailty focus on physical assessment of the patients. ${ }^{5}$ However, psychological and social domains of frailty seem to be very important and yet understudied. Instruments which focus on the physical dimension of frailty do not assess psychological and social risk factors of frailty, thus may overlook many patients with frailty. Because psychological disorders like depression and social factors such as loneliness increase the risk of frailty, ${ }^{6,7}$ instruments that do not assess these factors may lead to underestimation of patients at risk. According to a recent systematic review, the best instruments to evaluate frailty in primary care were Tilburg Frailty Indicator (TFI) and Share Frailty Index. ${ }^{8}$ In another review, which evaluated 38 different multicomponent frailty assessment tools, the TFI was one of the best in terms of psychometric assessment. ${ }^{5}$ Because of its ease of use in clinical practice, the TFI underwent language validation in many countries 
and was shown to be clinically useful in cross-sectional and longitudinal studies. ${ }^{9-15}$ Although the older adult population in Turkey is growing fast, to our knowledge the TFI has not been used in any clinical studies in the Turkish population. There is need for cross-cultural adaption of multidimensional frailty assessment tools to Turkish. In this study, we aimed to carry out Turkish language validation of the TFI.

\section{Methods}

\section{Study design and participants}

We carried out this cross-sectional study in the geriatrics outpatient unit of a university hospital between January 2015 and February 2016. One geriatrician (YT) and physiotherapist (CK) filled in the TFI. We invited consecutive older adults who were admitted to our geriatrics outpatient clinic and did not bear any of the exclusion criteria and enrolled all of the participants who provided written informed consent for this study. The only inclusion criterion was being 70 years old or older. Exclusion criteria were active malignancy, advanced stage dementia (a mini mental state examination score of lower than 11 points), and acute medically or psychologically stressful conditions.

\section{Ethical statement}

The ethical committee of Istanbul University, Istanbul School of Medicine approved the study protocol (no.: 2015/1253). The study was conducted in accordance with the Declaration of Helsinki.

\section{The Tilburg Frailty Indicator}

The TFI constitutes of 15 self-reported questions about physical (8 items), psychological (4 items), and social (3 items) domains of frailty. All of them are yes/no questions. The total score ranges between 0 and 15 ( 0 or 1 point for each item) and higher scores indicate more severe frailty. The authors of the original TFI recommend categorization of the subjects as frail if their total score is 5 or higher. ${ }^{1}$

\section{Translation procedure}

We used a standard guideline as performed by Uchmanowicz et $\mathrm{al}^{13}$ in the translation and cultural adaptation of the English version of the TFI into Turkish. First, we obtained permission for the use and translation of the questionnaire and two academicians independently translated the TFI from English to Turkish, discussed on the discrepancies, and decided on the final draft version. Afterward, a panel of ten competent geriatrician referees who had at least ten years of experience working with older people evaluated the draft translation for appropriateness and clarity. After the referees reached a consensus about the final version, a bilingual translator performed the back-translation process from Turkish to English. We sent the back-translated final version to the authors of the original instrument and they approved the back-translated final version with no comments.

\section{Other study variables}

We recorded the demographic characteristics such as age, gender, marital and educational status, and monthly income.

\section{Statistical analysis}

We used IBM SPSS for Windows version 21 (IBM corporation, Armonk, NY, USA) for the analyses. We presented categorical data as numbers and percentages and continuous data as means \pm SDs or medians (interquartile ranges [IQRs]) as needed. We assessed the normality of distribution of continuous variables using the Kolmogorov-Smirnov test. We used Cronbach's alpha values to evaluate the internal consistency of the Turkish TFI scale and intraclass correlation coefficient (ICC, in 16 of the study subjects) to assess inter-observer (on the same day) and test-retest variability (one week apart). We used the chi-squared test to compare categorical variables; and Student $t$-test or Mann-Whitney U-test for comparison of continuous data. We tested the correlation of the total score of each domain with total score of the TFI using Spearman correlation test. A correlation coefficient of $0.1-0.3,0.3-0.5$, and $>0.5$ indicated weak, moderate, and strong correlations, respectively. In all analyses, we accepted a two-sided $P$-value of $<0.05$ as statistically significant.

\section{Results}

A total of 198 participants $(n=62,31.3 \%$ males $)$ with a mean age of 77.7 \pm 5.5 (range 70-95) were enrolled. General characteristics of these subjects are shown in Table 1. We present the scores of each item and domain of the TFI in Table 2. The mean total score was $5.7 \pm 2.9$ and the rate of frailty was $63.6 \%(n=126)$ according to the aforementioned criteria.

There was no association between frailty and gender (64.7\% of women and $61.3 \%$ of men were frail, $P=0.6$ ). The mean age of the frail subjects tended to be higher than those without frailty, but the difference was not significant (78.3 \pm 5.7 vs $76.8 \pm 5.2, P=0.066$ ). There was no association between frailty and marital or educational status. There was a weak and negative correlation between total frailty score and reported monthly income $(r=-0.18, P=0.015)$. 
Table I General characteristics of the study population $(n=198)$

\begin{tabular}{|c|c|}
\hline Variables & n (\%) \\
\hline \multicolumn{2}{|l|}{ Sex } \\
\hline Females & $136(68.7)$ \\
\hline Males & $62(31.3)$ \\
\hline \multicolumn{2}{|l|}{ Marital status } \\
\hline Married & $83(42)$ \\
\hline With partner & $2(1)$ \\
\hline Single & $7(3.5)$ \\
\hline Separated & $\mathrm{I}(0.5)$ \\
\hline Divorced & $3(1.5)$ \\
\hline Widowed & $102(51.5)$ \\
\hline \multicolumn{2}{|l|}{ Education } \\
\hline Illiterate & $21(10.6)$ \\
\hline Literate & $25(12.8)$ \\
\hline First school graduate & $76(38.8)$ \\
\hline Secondary school graduate & $25(12.8)$ \\
\hline High school graduate & $25(12.8)$ \\
\hline College graduate & $20(10.2)$ \\
\hline Postgraduate & $4(2)$ \\
\hline \multicolumn{2}{|l|}{ Age groups (years) } \\
\hline $70-75$ & $83(41.9)$ \\
\hline $76-80$ & $53(26.8)$ \\
\hline $8 I-85$ & $44(22.2)$ \\
\hline$\geq 86$ & $18(9.1)$ \\
\hline \multicolumn{2}{|l|}{ Monthly income (TL) } \\
\hline$<1,000$ & $4 I(20.9)$ \\
\hline $1,000-2,000$ & $95(48.5)$ \\
\hline $2,000-3,000$ & $32(16.3)$ \\
\hline$>3,000$ & $28(14.3)$ \\
\hline
\end{tabular}

Abbreviation: TL, Turkish liras.

The Cronbach's alpha value of the TFI was 0.68 and ranged between 0.62 and 0.7 when each of the items was removed. Correlation of the corrected item and total score (ranged between -0.05 and 0.57 ); and the Cronbach's alpha values after removing each of the items are listed in Table 3. Total physical and psychological scores had strong correlation with the total score ( $r=0.89$ and 0.71 , respectively, $P<0.001$ for each), while the total social score had moderate correlation with the total score $(r=0.33, P<0.001)$. There was a good agreement between two assessments $(\mathrm{ICC}=0.99)$ and between two observers (ICC $=0.99$ ).

\section{Discussion}

We aimed to adapt and test the reliability of a Turkish version of the TFI. Frailty is a very common syndrome among older people. The TFI evaluates frailty in physical, psychological, and social domains. Thus, it is important to test the reliability of the TFI in different languages and cultures. TFI has already been shown to be a valid and reliable instrument to detect frailty in various languages. ${ }^{9-15} \mathrm{We}$ used established and widely accepted methods to adapt and test the reliability of a Turkish version. The Cronbach's alpha and ICC values suggest that the Turkish version of the TFI had good internal consistency and test-retest and inter-observer variability. The results of our study suggest that Turkish version of the TFI is valid and reliable.

We confirmed that the Turkish version of the TFI had an acceptable internal consistency. The Cronbach's alpha value was 0.68 , thus it was comparable with Polish, Brazilian, and Dutch versions, which had Cronbach's alpha values of $0.72,0.78$, and 0.79 , respectively. ${ }^{10,13,16}$ While the total physical score had the strongest correlation with the total score, the psychological score also had a strong correlation with the total score. Four of the strongest corrected item-total score correlations were among the physical domain. All of the items of the physical domain except for unintentional weight loss $(r=0.06)$, hearing loss $(r=0.16)$, and vision problems $(r=0.29)$ had moderate to strong correlations with the total score and the correlation coefficient ranged between 0.39 and 0.57 . Items of the psychological domain had weak to moderate correlations with the total score (range 0.21-0.42). These findings suggest that physical domain is the most important component of the TFI because more than half of the total score ( 8 of 15 items) comes from the physical domain and most of the items of the physical domain has moderate to strong correlations with the total score. The items of the psychological domain also had weak to moderate correlations with the total score and total psychological score had a strong correlation with the total score. Thus, psychological domain of the TFI seems to be the second important component of the TFI. However, social items had the weakest corrected correlation values with the total test scores (between -0.05 and 0.1 ). Because most of the older subjects in geriatrics clinics in Turkey are attended by their relatives, social problems are possibly less common in these people compared with the general population. It would be very hard for a frail older adult who has little or no social support to admit to a university clinic. Such older adults generally receive health care service from the primary care services. Thus, our results may not be generalized to the general population. Furthermore, this may be a specific limitation of the TFI in countries where frail subjects are 
Table 2 Scores of the individual domains and items of the Tilburg Frailty Indicator

\begin{tabular}{|c|c|c|c|}
\hline Variables & Mean \pm SD & Median & IQR \\
\hline Physical domain & $3.23 \pm 2.05$ & 3 & 3 \\
\hline $\begin{array}{l}\text { I. Kendinizi fiziksel olarak sağlıklı hissediyor musunuz? } \\
\text { (Do you feel physically healthy?) }\end{array}$ & $0.2 \pm 0.4$ & 0 & 0 \\
\hline $\begin{array}{l}\text { 2. Son dönemde istem dıșı olarak çok fazla kilo kaybettiniz mi? } \\
\text { (Have you lost a lot of weight recently without wishing to do so?) }\end{array}$ & $0.1 \pm 0.3$ & 0 & 0 \\
\hline $\begin{array}{l}\text { 3. Günlük hayatınızda yürümekte zorlanma nedeniyle sorun yașıyor musunuz? } \\
\text { (Do you experience problems in your daily life due to difficulty in walking?) }\end{array}$ & $0.5 \pm 0.5$ & 0.5 & 1 \\
\hline $\begin{array}{l}\text { 4. Günlük hayatınızda dengenizi sağlamakta zorlanma nedeniyle sorun yașıyor musunuz? } \\
\text { (Do you experience problems in your daily life due to difficulty maintaining your balance?) }\end{array}$ & $0.49 \pm 0.5$ & 0 & 1 \\
\hline $\begin{array}{l}\text { 5. Günlük hayatınızda ișitme azlığı nedeniyle sorun yașıyor musunuz? } \\
\text { (Do you experience problems in your daily life due to poor hearing?) }\end{array}$ & $0.57 \pm 0.5$ & 1 & 1 \\
\hline $\begin{array}{l}\text { 6. Günlük hayatınızda görme azlığı nedeniyle sorun yașıyor musunuz? } \\
\text { (Do you experience problems in your daily life due to poor vision?) }\end{array}$ & $0.6 \pm 0.5$ & 1 & 1 \\
\hline $\begin{array}{l}\text { 7. Günlük hayatınızda ellerinizde güçsüzlük nedeniyle sorun yașıyor musunuz? } \\
\text { (Do you experience problems in your daily life due to lack of strength in your hands?) }\end{array}$ & $0.31 \pm 0.46$ & 0 & 1 \\
\hline $\begin{array}{l}\text { 8. Günlük hayatınızda fiziksel yorgunluk nedeniyle sorun yașıyor musunuz? } \\
\text { (Do you experience problems in your daily life due to physical tiredness?) }\end{array}$ & $0.45 \pm 0.5$ & 0 & 1 \\
\hline Psychological domain & $1.11 \pm 0.73$ & 1 & 1 \\
\hline $\begin{array}{l}\text { 9. Hafızanız ile ilgili sorunlarınız var mı? } \\
\text { (Do you have problems with your memory?) }\end{array}$ & $0.39 \pm 0.5$ & 0 & I \\
\hline $\begin{array}{l}\text { 10. Geçtiğimiz ay boyunca kendinizi keyifsiz/moralsiz hissettiniz mi? } \\
\text { (Have you felt down during the last month?) }\end{array}$ & $0.43 \pm 0.5$ & 0 & 1 \\
\hline $\begin{array}{l}\text { II. Geçtiğimiz ay boyunca kendinizi sinirli/gergin veya endișeli hissettiniz mi? } \\
\text { (Have you felt nervous or anxious during the last month?) }\end{array}$ & $0.42 \pm 0.5$ & 0 & 1 \\
\hline $\begin{array}{l}\text { I2. Sorunlarla iyi bir șekilde bașa çıkabiliyor musunuz? } \\
\text { (Are you able to cope with problems well?) }\end{array}$ & $0.12 \pm 0.3$ & 0 & 0 \\
\hline Social domain & $1.36 \pm 1.15$ & $\mathrm{I}$ & 2 \\
\hline $\begin{array}{l}\text { 13. Yalnız mı yașıyorsunuz? } \\
\text { (Do you live alone?) }\end{array}$ & $0.25 \pm 0.43$ & 0 & 0.25 \\
\hline $\begin{array}{l}\text { 14. Bazen etrafınızda birilerinin olmasını özlüyor musunuz? } \\
\text { (Do you sometimes miss having people around you?) }\end{array}$ & $0.64 \pm 0.48$ & 1 & 1 \\
\hline $\begin{array}{l}\text { I5. Diğer insanlardan yeterince destek görüyor musunuz? } \\
\text { (Do you receive enough support from other people?) }\end{array}$ & $0.22 \pm 0.42$ & 0 & 0 \\
\hline
\end{tabular}

Notes: The items of the Tilburg Frailty Indicator were obtained from the article which was published in Journal of the American Medical Directors Association., I I (5), Gobbens RJ, van Assen MA, Luijkx KG, Wijnen-Sponselee MT, Schols JM, The Tilburg Frailty Indicator: psychometric properties, 344-355, Copyright Elsevier (20I0).

almost always attended by their relatives in geriatrics outpatient clinics. However, further studies are needed to come to strict conclusions about this issue.

The test-retest variability and inter-observer variability were very good given their ICC values ( 0.99 for each). This finding indicates that the Turkish version of the TFI is reliable and reproducible.

A recently published systematic review indicates that the TFI is a valid and reliable screening tool, but its diagnostic accuracy is not well established. ${ }^{17}$ Because Turkey is among the fast aging countries, it is crucial to have such multidimensional frailty assessment tools such as the TFI at hand. This way, we will be able to use such frailty data in longitudinal studies and observe its predictive value in terms of morbidity and mortality. ${ }^{17}$ Recent data indicate that performing multidimensional assessment using the TFI gives predictive information about falls in the next year. ${ }^{18}$ Similarly, several recent studies indicated that several indices of frailty were closely related with 12-month all-cause mortality after transcatheter aortic valve implantation. ${ }^{19,20}$ However, a multidimensional tool such as the TFI was not used in these studies. We suggest that the use of the TFI in cross-sectional and longitudinal studies in different patient populations would give further information about its diagnostic and prognostic value.

We used the Turkish version of the TFI to determine the rate of frailty in a relatively large sample that consisted of community-dwelling outpatients of a geriatrics clinic. We observed a relatively high rate of frailty. The rate of frailty was 
Table 3 Reliability of the Turkish version of the Tilburg Frailty Indicator

\begin{tabular}{|c|c|c|}
\hline Variables & $\begin{array}{l}\text { Corrected item-total } \\
\text { correlation }\end{array}$ & $\begin{array}{l}\text { Cronbach's alpha if } \\
\text { item deleted }\end{array}$ \\
\hline Physical domain & $0.89^{a}$ & \\
\hline $\begin{array}{l}\text { I. Kendinizi fiziksel olarak sağlıkı hissediyor musunuz? } \\
\text { (Do you feel physically healthy?) }\end{array}$ & 0.46 & 0.64 \\
\hline $\begin{array}{l}\text { 2. Son dönemde istem dıșı olarak çok fazla kilo kaybettiniz mi? } \\
\text { (Have you lost a lot of weight recently without wishing to do so?) }\end{array}$ & 0.06 & 0.68 \\
\hline $\begin{array}{l}\text { 3. Günlük hayatınızda yürümekte zorlanma nedeniyle sorun yașıyor musunuz? } \\
\text { (Do you experience problems in your daily life due to difficulty in walking?) }\end{array}$ & 0.45 & 0.64 \\
\hline $\begin{array}{l}\text { 4. Günlük hayatınızda dengenizi sağlamakta zorlanma nedeniyle sorun yașıyor musunuz? } \\
\text { (Do you experience problems in your daily life due to difficulty maintaining your balance?) }\end{array}$ & 0.42 & 0.64 \\
\hline $\begin{array}{l}\text { 5. Günlük hayatınızda ișitme azlığı nedeniyle sorun yașıyor musunuz? } \\
\text { (Do you experience problems in your daily life due to poor hearing?) }\end{array}$ & 0.16 & 0.68 \\
\hline $\begin{array}{l}\text { 6. Günlük hayatınızda görme azlığı nedeniyle sorun yașıyor musunuz? } \\
\text { (Do you experience problems in your daily life due to poor vision?) }\end{array}$ & 0.29 & 0.66 \\
\hline $\begin{array}{l}\text { 7. Günlük hayatınızda ellerinizde güçsüzlük nedeniyle sorun yașıyor musunuz? } \\
\text { (Do you experience problems in your daily life due to lack of strength in your hands?) }\end{array}$ & 0.44 & 0.64 \\
\hline $\begin{array}{l}\text { 8. Günlük hayatınızda fiziksel yorgunluk nedeniyle sorun yașıyor musunuz? } \\
\text { (Do you experience problems in your daily life due to physical tiredness?) }\end{array}$ & 0.57 & 0.62 \\
\hline Psychological domain & $0.7 \mathrm{I}^{\mathrm{a}}$ & \\
\hline $\begin{array}{l}\text { 9. Hafızanız ile ilgili sorunlarınız var mı? } \\
\text { (Do you have problems with your memory?) }\end{array}$ & 0.3 & 0.66 \\
\hline $\begin{array}{l}\text { 10. Geçtiğimiz ay boyunca kendinizi keyifsiz/moralsiz hissettiniz mi? } \\
\text { (Have you felt down during the last month?) }\end{array}$ & 0.42 & 0.64 \\
\hline $\begin{array}{l}\text { II. Geçtiğimiz ay boyunca kendinizi sinirli/gergin veya endișeli hissettiniz mi? } \\
\text { (Have you felt nervous or anxious during the last month?) }\end{array}$ & 0.21 & 0.67 \\
\hline $\begin{array}{l}\text { I2. Sorunlarla iyi bir șekilde bașa çıkabiliyor musunuz? } \\
\text { (Are you able to cope with problems well?) }\end{array}$ & 0.39 & 0.65 \\
\hline Social domain & $0.33^{\mathrm{a}}$ & \\
\hline $\begin{array}{l}\text { 13. Yalnız mı yașıyorsunuz? } \\
\text { (Do you live alone?) }\end{array}$ & -0.05 & 0.7 \\
\hline $\begin{array}{l}\text { 14. Bazen etrafınızda birilerinin olmasını özlüyor musunuz? } \\
\text { (Do you sometimes miss having people around you?) }\end{array}$ & 0.07 & 0.69 \\
\hline $\begin{array}{l}\text { 15. Diğer insanlardan yeterince destek görüyor musunuz? } \\
\text { (Do you receive enough support from other people?) }\end{array}$ & 0.1 & 0.68 \\
\hline
\end{tabular}

Notes: aSpearman correlation test. The items of the Tilburg Frailty Indicator were obtained from the article which was published in Journal of the American Medical Directors Association., II(5), Gobbens RJ, van Assen MA, Luijkx KG, Wijnen-Sponselee MT, Schols JM, The Tilburg Frailty Indicator: psychometric properties, 344-355, Copyright Elsevier (2010).

around $30 \%$ and $40 \%$, respectively, in the Brazilian and Polish studies. ${ }^{10,11}$ We suggest that the relatively high mean age of our study population and the setting of the study (a university hospital) might have led to such a relatively high rate of frailty. Given the fact that most of the commonly utilized frailty assessment instruments evaluate only physical frailty and report a prevalence around $10 \%$ in community-dwelling older adults, ${ }^{21}$ one would expect a higher rate of frailty with the TFI.

\section{Limitations}

The present study has some limitations. First, the study focused on the reliability and linguistic properties of the TFI and more studies are needed to show its validity to detect frailty and to predict its adverse outcomes. Second, the TFI has originally been developed as a self-report instrument but in this study the observers filled in the scale.

\section{Conclusion}

Our study showed that the Turkish version of the TFI is a reliable and reproducible tool for the assessment of frailty among a Turkish population.

\section{Abbreviations}

TFI, Tilburg Frailty Indicator; ICC, intraclass correlation coefficient. 


\section{Acknowledgment}

We thank RJJ Gobbens for his permission to adapt and translate the TFI into Turkish and also for his support.

\section{Disclosure}

The authors report no conflicts of interest in this work.

\section{References}

1. Gobbens RJ, van Assen MA, Luijkx KG, Wijnen-Sponselee MT, Schols JM. The Tilburg frailty indicator: psychometric properties. $J$ Am Med Dir Assoc. 2010;11(5):344-355.

2. Fried LP, Tangen CM, Walston J, et al. Frailty in older adults: evidence for a phenotype. J Gerontol A Biol Sci Med Sci. 2001;56(3):M146-M157.

3. Santiago LM, Gobbens RJJ, van Assen M, Carmo CN, Ferreira DB, Mattos IE. Predictive validity of the Brazilian version of the Tilburg frailty indicator for adverse health outcomes in older adults. Arch Gerontol Geriatr. 2018;76:114-119.

4. Wei K, Nyunt MS, Gao Q, Wee SL, Yap KB, Tp NG. Association of frailty and malnutrition with long-term functional and mortality outcomes among community-dwelling older adults: results from the Singapore longitudinal aging study 1. JAMA. 2019;1(3):e180650.

5. Sutton JL, Gould RL, Daley S, et al. Psychometric properties of multicomponent tools designed to assess frailty in older adults: a systematic review. BMC Geriatr. 2016;16(1):55.

6. Gale CR, Westbury L, Cooper C. Social isolation and loneliness as risk factors for the progression of frailty: the English longitudinal study of ageing. Age Ageing. 2018;47(3):392-397.

7. Zou C, Chen S, Shen J, et al. Prevalence and associated factors of depressive symptoms among elderly inpatients of a Chinese tertiary hospital. Clin Interv Aging. 2018;13:1755-1762.

8. Pialoux T, Goyard J, Lesourd B. Screening tools for frailty in primary health care: a systematic review. Geriatr Gerontol Int. 2012;12(2): 189-197.

9. Coelho T, Santos R, Paúl C, Gobbens RJ, Fernandes L. Portuguese version of the Tilburg frailty indicator: transcultural adaptation and psychometric validation. Geriatr Gerontol Int. 2015;15(8):951-960.
10. Santiago LM, Luz LL, Mattos IE, Gobbens RJ, van Assen MA. Psychometric properties of the Brazilian version of the Tilburg frailty indicator (TFI). Arch Gerontol Geriatr. 2013;57(1):39-45.

11. Uchmanowicz I, Jankowska-Polańska B, Uchmanowicz B, Kowalczuk K, Gobbens RJ. Validity and reliability of the Polish version of the Tilburg frailty indicator (TFI). J Frailty Aging. 2016;5(1):27-32.

12. Andreasen J, Sørensen EE, Gobbens RJ, Lund H, Aadahl M. Danish version of the Tilburg Frailty Indicator - translation, cross-cultural adaption and validity pretest by cognitive interviewing. Arch Gerontol Geriatr. 2014;59(1):32-38.

13. Uchmanowicz I, Jankowska-Polańska B, Łoboz-Rudnicka M, Manulik S, Łoboz-Grudzień K, Gobbens RJ. Cross-cultural adaptation and reliability testing of the Tilburg frailty indicator for optimizing care of Polish patients with frailty syndrome. Clin Interv Aging. 2014;9:997-1001.

14. Mulasso A, Roppolo M, Gobbens RJ, Rabaglietti E. The Italian version of the Tilburg frailty indicator: analysis of psychometric properties. Res Aging. 2016;38(8):842-863.

15. Freitag $\mathrm{S}, \mathrm{Schmidt} \mathrm{S}$, Gobbens RJ. Tilburg frailty indicator. German translation and psychometric testing. Z Gerontol Geriatr. 2016;49(2): 86-93.

16. van Assen MA, Pallast E, Fakiri FE, Gobbens RJ. Measuring frailty in Dutch community-dwelling older people: reference values of the Tilburg frailty indicator (TFI). Arch Gerontol Geriatr. 2016;67:120-129.

17. Apóstolo J, Cooke R, Bobrowicz-Campos E, et al. Predicting risk and outcomes for frail older adults: an umbrella review of frailty screening tools. JBI Database System Rev Implement Rep. 2017;15(4):1154-1208.

18. Mulasso A, Roppolo M, Gobbens RJ, Rabaglietti E. Mobility, balance and frailty in community-dwelling older adults: what is the best 1-year predictor of falls? Geriatr Gerontol Int. 2017;17(10): $1463-1469$.

19. Kleczynski P, Dziewierz A, Bagienski M, et al. Impact of frailty on mortality after transcatheter aortic valve implantation. Am Heart $J$. 2017;185:52-58.

20. Goudzwaard JA, de Ronde-Tillmans M, El Faquir N, et al. The Erasmus Frailty Score is associated with delirium and 1-year mortality after Transcatheter Aortic Valve Implantation in older patients. The TAVI Care \& Cure program. Int J Cardiol. 2019;276:48-52.

21. Collard RM, Boter H, Schoevers RA, Oude Voshaar RC. Prevalence of frailty in community-dwelling older persons: a systematic review. J Am Geriatr Soc. 2012;60(8):1487-1492.
Clinical Interventions in Aging

\section{Publish your work in this journal}

Clinical Interventions in Aging is an international, peer-reviewed journal focusing on evidence-based reports on the value or lack thereof of treatments intended to prevent or delay the onset of maladaptive correlates of aging in human beings. This journal is indexed on PubMed Central, MedLine,

\section{Dovepress}

CAS, Scopus and the Elsevier Bibliographic databases. The manuscript management system is completely online and includes a very quick and fair peer-review system, which is all easy to use. Visit http://www.dovepress. com/testimonials.php to read real quotes from published authors. 